RODNO MJESTO FUDBALERA BRAZILSKOG NACIONALNOG TIMA I NJIHOVO UČEŠĆE NA SVJETSKIM PRVENSTVIMA

\section{THE BIRTHPLACE OF SOCCER PLAYERS OF BRAZILIAN NATIONAL TEAM IN WORLD CUPS}

Luis Antonio Verdini de Carvalho ${ }^{1}$,João Felipe Machado $^{1,2}$,Ana Paula Soares de Sousa ${ }^{1,2}$,José Fernandes Filho ${ }^{1,2}$

${ }^{1}$ Universidade Federal do Rio de Janeiro

${ }^{2}$ Laboratório de Biociéncias do Movimento Humano - LABIMH

Kratki naučni članak doi:10.5550/sgia.181401.se.cms UDC:796.332(81)

Received: 08.09.2017. Approved: 21.06.2018.

Coresponding author:

Luis Antonio Verdini de Carvalho verdini@eefd.ufrj.br

Sportlogia 2018, 14 (1),86-92.

E-ISSN 1986-6119

\title{
SAŽETAK
}

Studija ima za cilj da identifikuje region u kojem su rođeni igrači iz muških brazilskih nogometnih reprezentacija $i$ koji su predstavljali prvi timo Brazila na svjetskim prvenstvima. Analizirani su svi igrači koji su predstavljali Brazilsku reprezentaciju na svim svjetskim prvenstvima koje je organizovala FIFAu periodu od 1930. do 2014. godine. Brazilski fudbal ostvaruje zapažene rezultate širom svijeta u vezi sa svjetskimkim kupovima i obezbjeđivanjem vrhunskih igrača na fudbalskom tržištu u različitim zemljama. Rezultat pokazuje da je raspodjela heterogena prema mjestu rođenja fudbalera. Jugoistočni i južni regioni koncentrišu 86,6\% mjesta rođenja i samo dvije federativne jedinice - Sao Paulo i Rio de Janeiro imaju 63,46\%. Porijeklo fudbalera $i$ vezu sa učešćem za reprezentaciju Brazila trebalo bi detaljnije proučavati kako bi se našla povezanost sa nastupom za brazilski tim.

Ključne riječi: fudbal, reprezentacija Brazila, mjesto rođenja

Carvalho, L.A., Machado, J.F., Sousa, A.P., \& Filho, H.F. (2018). Rodno mjesto fudbalera brazilskog nacionalnog tima i njhovo učeće na svjetskim prvenstvima. Sportlogia, 14 (1), 86-92. 


\section{INTRODUCTION}

Soccer it is one of the most played sports worldwide. FIFA(Football International Football Association) is the organization body that controls soccer all over the world with 209 National Federations (FIFA.com, n.d.-b). It has more associated than UN ( United Nations ), 193 countries ('Países-membros - ONU', 2014).

The financial resources involved in soccer and in the player formation to become professional it is very high Soccer worldwide it is a great business. Accordingly with the final report from the Modernizing Plan-Brazilian Soccer . (2000), done by Getulio Vargas Foundation ( FGV ). Including direct agents, clubs and federations . And indirects, like sports kits - and the midia. The soccer in the world movies around 250 billions us dollars per year .In Brazil, the same report shows that soccer it is an economic activity with great capacity to provide jobs, with multiplier effect bigger than traditional sectors, accounting ; 300 thousand direct jobs - 30 million players ( formal and not ) - 580 thousand participants in 13 thousand teams that are involved in organized games ( formal sport ) - 580 stadiums with capacity to receive 5.5 millions supporters - around 500 professional clubs playing an average of 90 matches per year - regarding sports materials and playing kits, it is around 9 million boots for soccer and fut 5 a side , 6 millions balls and 32 millions t shirts (Leoncini \& Silva, 2005). The Brazilian trade and commerce has huge influence from soccer .Soccer business has a considerable weigh in the Brazilian export industry .Selling players to clubs outside Brazil represented an increase of 34\% in 2005 ( around 6 billion us dollars ). It represents $40 \%$ of the Brazilian export services ( in 2005 , all the Brazilian export services was around 16 billion us dollars ) (Alcântara, 2006) .

Brazil holds an outstanding position in soccer, being so, it is necessary a detailed knowledge about the players to serve as reference to develop soccer in all Brazilian regions, increasing the possibilities to form new professional players . "Brazil is outstanding in the world soccer market, providing several professionals , especially players, to all the world " (SOARES, 2010).

The search to become professional in soccer in Brazil it is impressive ." Studies about detecting and training talented players in soccer indicates that the market has as support a new type of professional formation agent, that enroll youth teenagers, generally, that belongs to the groups popular - medium part of the population"(Guedes, 1998). 
UP to now , we have had 20 World Cups, since 1930 till 2014 . There were no World Cup in 1938 , 1942 , 1946 , due to the World War II. Brazil is the biggest winner with 5 titles . Italy and Germany with 4 titles Uruguai and Argentine 2 titles . France, England and Spain 1 (FIFA.com, n.d.-a).

Brazil has continental dimensions. With 5 big regions ( midwest, northeast, north, southeast and south ), subdivided in 26 federative units ( states ), plus the Federal District, like this ; Midwest region ; Federal District, Goias , Mato Grosso and Mato Grosso do sul; Northeast region ; Alagoas , Bahia , Ceará, Maranhão, Paraíba, Pernambuco , Piauí , Rio Grande do Norte and Sergipe; North region ; Acre, Amapá, Amazonas , Pará, Rondônia , Roraima and Tocantins; Southeast region ; Espírito Santo , Minas Gerais , Rio de Janeiro and São Paulo ; South region : Paraná, Santa Catarina and Rio Grande do Sul .

The birthplace indicates where there is a big probability to live, in this case, initiate the soccer practice. At least $85,1 \%$ from the Brazilians, they live in the birthplace .See the table1 (Justo \& Neto, 2009) :

Table 1 - Dimension from the internal migration in Brasil - 1980-2000 ource : Census Demographic from 1980, 1991 and 2000.IBGE

\begin{tabular}{|c|c|c|c|}
\hline & 1980 & 1991 & 2000 \\
\hline $\begin{array}{c}\text { Numero de } \\
\text { migrantes }\end{array}$ & 15.809 .743 & 21.435 .954 & 25.530 .231 \\
\hline $\begin{array}{c}\text { Relação } \\
\text { migrantes/população }\end{array}$ & 12,9 & 14,4 & 14,9 \\
\hline
\end{tabular}

Source : Census Demographic from 1980, 1991 and 2000.IBGE

The studied must indicate where soccer has a better structure and development by showing low index of birthplace from the players . " the success in soccer depends on many external reasons, like, training structure, multidisciplinary team , personal factors, social and cultural from the players "(Soares, De Melo, \& Da Costa, 2011).

Carvalho, L.A., Machado, J.F., Sousa, A.P., \& Filho, H.F. (2018). Rodno mjesto fudbalera brazilskog nacionalnog tima i njhovo učeće na svjetskim prvenstvima. Sportlogia, 14 (1), 86-92. 
The objective from this study was to identify the geographic distribution, Region and Federal Unit, the birthplace of the soccer players from the Brazilian national teams in the World Cups .

\section{METHODS}

The work it is original with research Theoretic Empiric, type descriptive, with transversal line, regarding the Approach and with etiology ex-post-facto , about the technical procedures.

The population was compost by 312 athletes that participated in all World Cups organized by the Federation International Football Association, from 1930 up to 2014 , by the Brazilian 1st National Team. The informations were collected in the web ( site www.ogol.com )('www.ogol.com.br', n.d.) from the athletes of the National Teams. The informations were presented in absolute numbers by the quantity of players in each state and in percentage form referring to the region and to the state of the birthplace of each player .

The information analyzes of the birthplace, specifically region and Federal Unit, was done by descriptive statistic, using parameters of percentage distribution . To enter and storage the informations was used the program Microsoft Excel 2010 version .

\section{RESULTS}

The registers showed the distribution related to the players quantity in table 2:

Table 2- Birth of soccer players

\begin{tabular}{|l|c|}
\hline Federal Unit & Number of Births \\
\hline São Paulo & 103 \\
\hline Rio de Janeiro & 95 \\
\hline Minas Gerais & 29 \\
\hline Rio Grande do Sul & 28 \\
\hline Bahia & 12 \\
\hline Pernambuco & 10 \\
\hline Paraná & 09 \\
\hline Pará & 05 \\
\hline
\end{tabular}

Carvalho, L.A., Machado, J.F., Sousa, A.P., \& Filho, H.F. (2018). Rodno mjesto fudbalera brazilskog nacionalnog tima i njhovo učeće na svjetskim prvenstvima. Sportlogia, 14 (1), 86-92. doi: 10.5550/sgia.181401.se.cms 


\begin{tabular}{|l|l|}
\hline Paraíba & 04 \\
\hline Espírito Santo & 03 \\
\hline Alagoas & 02 \\
\hline Distrito Federal & 02 \\
\hline Mato Grosso do Sul & 02 \\
\hline Rio Grande do Norte & 02 \\
\hline Maranhão & 01 \\
\hline Sergipe & 01 \\
\hline
\end{tabular}

\section{DISCUSSION}

It was observed in this study that there is an heterogenous distribution between the regions and the Brazilian Federal Units regarding the birthplace of the soccer players who represented Brazil National Teams in World Cups . That might indicates, probably, that exists more investment in the south east - south and north east regions , respectively, while in mid west and north regions the investment appear to be very low . Being so , based on such informations, we can conclude : to potentialize the discover and development of talents for soccer, it is necessary a better planning and bigger investment, mainly on the north and mid west regions .

Regarding the Federal Units, it was possible observed a polarization in the link Sao Paulo / Rio de Janeiro and a significant representation fromMinas Gerais, Rio Grande do Sul, Bahia, Pernambuco and Paraná, and the others 20 Federal Units presents far results comparing with these 7 mentioned . " there are worry gaps for the development of the sport in high level in the country, committing the performance in a long term "(Mazei, Bastos, BÖHME, \& Bosscher, 2014)

\section{CONCLUSION}

These results de demonstrated a predominance in the south East region with $73,72 \%$ of the players birthplace ; followed by the south region with $13,14 \%$; north east region with $10,26 \%$; north region with $1,60 \%$ and midwest region with $1.08 \%$. 
To give a better characteristic to the formation process of the soccer players, we suggest that new studies are done, searching not only the birthplace of the soccer players, but also others important factors, like for example, the player formation place, the formation time on the base categories, among others. Still must be study in each Federal Unit how was presented the informations regarding the cities of birthplace of the soccer players .

\section{REFERENCES}

Alcântara, H. (2006). A magia do futebol. Estudos Avançados, 20(57), 297-313. https://doi.org/10.1590/S0103-40142006000200021

FIFA.com. (n.d.-a). 2018 FIFA World Cup Russia ${ }^{\text {TM }}$ - Qualifiers. Retrieved 10 August 2016, from http://www.fifa.com/worldcup/preliminaries/index.html

FIFA.com. (n.d.-b). FIFA Associations and Confederations. Retrieved 10 August 2016, from http://www.fifa.com/associations/index.html

Guedes, S. L. (1998). O Brasil no campo de futebol: estudos antropológicos sobre os significados do futebol brasileiro (Vol. 16). Editora Da Universidade Federal Fluminense.

Justo, W. R., \& Neto, R. da M. S. (2009). Quem são e para onde vão os migrantes no Brasil? O perfil do migrante interno brasileiro. Revista Da ABET, 8(1). Retrieved from http://www.ies.ufpb.br/ojs/index.php/abet/article/view/15262

Leoncini, M. P., \& Silva, M. da. (2005). Entendendo o futebol como um negócio: um estudo exploratório. Gestão \& Produção, 12(1), 11-23.

https://doi.org/10.1590/S0104-530X2005000100003

Mazei, L. C., Bastos, F. da C., BÖHME, M. T. S., \& Bosscher, V. D. (2014). Política do Esporte de Alto Rendimento no Brasil: Análise da estratégia de investimentos na 
confederações olímpicas. Revista Portuguesa de Ciencias Do Desporto, (14-2), 58-

73. https://doi.org/10.5628/rpcd.14.02.58

Países-membros - ONU. (2014, November 5). Retrieved from

https://nacoesunidas.org/conheca/paises-membros/

Soares, A. J. G., De Melo, L. B. S., \& Da Costa, F. R. (2011). JOGADORES DE FUTEBOL

NO BRASIL: MERCADO, FORMAÇÃO DE ATLETAS E ESCOLA. Rev. Bras.

Ciênc. Esporte, 33(4), 905-921.

SOARES, D. A. J. Gon. (2010). A pátria de chuteiras está desaparecendo? Retrieved from http://www.scielo.br/pdf/rbce/v32n1/v32n1a02

www.ogol.com.br. (n.d.).

\section{SUMMARY}

The study has the objective to identify the region where the players from the male Brazilian Soccer National Teams were born and that represented Brazil 1st teams in World Cups. It was analyzed all the players who represented Brazil 1st National Teams in all World Cups organized by Football International Football Association from 1930 to 2014 . The Brazilian soccer register expressive results worldwide regarding winning Cups and providing top players to the soccer market in different countries. The result shows that the distribution it is heterogeneous about the birthplace of the soccer players. The southeast and the south regions concentrate $86,6 \%$ of the born place and only two Federative Units. Sao Paulo and Rio de Janeiro have 63,46 \% . The professional soccer player origin, still needs deep studies to be oriented regarding potential demands into the formation of the soccer player .

Key Words: soccer, Brazilian national team, birthplace.

Primljeno: 08.09.2017.

Odobreno: 21.06.2018.

Korespodencija:

Luis Antonio Verdini de Carvalho

verdini@eefd.ufrj.br

Carvalho, L.A., Machado, J.F., Sousa, A.P., \& Filho, H.F. (2018). Rodno mjesto fudbalera brazilskog nacionalnog tima i njhovo učeće na svjetskim prvenstvima. Sportlogia, 14 (1), 86-92.

doi: $10.5550 /$ sgia.181401.se.cms 